\title{
Mitigation of enteric methane emissions through improving efficiency of energy utilization and productivity in lactating dairy cows
}

\author{
T. Yan, ${ }^{* 1}$ C. S. Mayne, ${ }^{*}$ F. G. Gordon, ${ }^{*}$ M. G. Porter, ${ }^{*}$ R. E. Agnew, ${ }^{*}$ D. C. Patterson, ${ }^{*}$ C. P. Ferris, ${ }^{*}$ \\ and D. J. Kilpatrick† \\ ${ }^{*}$ Agri-Food and Biosciences Institute, Hillsborough, Co. Down BT26 6DR, UK \\ †Agri-Food and Biosciences Institute, Newforge Lane, Belfast BT9 5PX, UK
}

\begin{abstract}
The data set used in the present study was obtained from 20 energy metabolism studies involving 579 lactating dairy cows (511 Holstein-Friesian, 36 Norwegian Red, and 32 Jersey-Holstein crossbreds) varying in genetic merit, lactation number, stage of lactation, and live weight. These cows were offered diets based on grass silage $(\mathrm{n}=550)$ or fresh grass $(\mathrm{n}=29)$, and their energy intake and outputs, including methane energy $\left(\mathrm{CH}_{4}-\mathrm{E}\right)$, were measured in indirect open-circuit respiration calorimeter chambers. The objective was to use these data to evaluate relationships between $\mathrm{CH}_{4}-\mathrm{E}$ output and a range of factors in animal production and energetic efficiency in lactating dairy cows under normal feeding regimens. The $\mathrm{CH}_{4}-\mathrm{E}$ as a proportion of milk energy output $\left(\mathrm{E}_{1}\right), \mathrm{E}_{1}$ adjusted to zero energy balance $\left(\mathrm{E}_{1(0)}\right)$, or intakes of gross energy (GE), digestible energy (DE), or metabolizable energy (ME) was significantly related to a wide range of variables associated with milk production $\left(\mathrm{E}_{1}\right.$ and $\left.\mathrm{E}_{1(0)}\right)$ and energy parameters (energy intake, metabolizability, partitioning, and utilization efficiencies). Three sets of linear relationships were developed with experimental effects removed. The $\mathrm{CH}_{4}-\mathrm{E} / \mathrm{GE}$ intake $\left(\mathrm{r}^{2}=0.50-0.62\right)$ and $\mathrm{CH}_{4}-\mathrm{E} / \mathrm{E}_{1}\left(\mathrm{r}^{2}=\right.$ 0.41-0.68) were reduced with increasing feeding level, $\mathrm{E}_{1} /$ metabolic body weight $\left(\mathrm{MBW} ; \mathrm{kg}^{0.75}\right), \mathrm{E}_{1(0)} / \mathrm{MBW}$, GE intake/MBW, DE intake/MBW, and ME intake/ $\mathrm{MBW}$. Increasing dietary $\mathrm{ME} / \mathrm{DE}$ decreased $\mathrm{CH}_{4}-\mathrm{E} / \mathrm{E}_{1}$ $\left(\mathrm{r}^{2}=0.46\right)$ and $\mathrm{CH}_{4}$-E/GE intake $\left(\mathrm{r}^{2}=0.72\right)$. Dietary $\mathrm{ME}$ concentration and ME/GE were also negatively related to $\mathrm{CH}_{4}-\mathrm{E} / \mathrm{GE}$ intake $\left(\mathrm{r}^{2}=0.47\right)$. However, increasing heat production/ME intake increased $\mathrm{CH}_{4}-\mathrm{E}$ as a proportion of $\mathrm{E}_{1}\left(\mathrm{r}^{2}=0.41\right), \mathrm{E}_{1(0)}\left(\mathrm{r}^{2}=0.67\right)$ and energy intake (GE, DE, and $\mathrm{ME} ; \mathrm{r}^{2}=0.62$ and 0.70 ). These proportional $\mathrm{CH}_{4}$-E variables were reduced with increasing ratios of $\mathrm{E}_{1} / \mathrm{ME}$ intake and $\mathrm{E}_{1(0)} / \mathrm{ME}$ intake and efficiency of ME use for lactation $\left(\mathrm{r}^{2}=0.49-0.70\right)$.
\end{abstract}

Received November 20, 2009.

Accepted February 10, 2010.

${ }^{1}$ Corresponding author: tianhai.yan@afbini.gov.uk
Fitting $\mathrm{CH}_{4}-\mathrm{E} / \mathrm{E}_{1}$ or $\mathrm{CH}_{4}-\mathrm{E} / \mathrm{E}_{1(0)}$ against these energetic efficiencies in quadratic rather than linear relationships significantly increased $\mathrm{r}^{2}$ values $(0.49-0.67$ vs. 0.59-0.87). In conclusion, $\mathrm{CH}_{4}-\mathrm{E}$ as a proportion of energy intake (GE, DE, and ME) and milk production $\left(\mathrm{E}_{1}\right.$ and $\left.\mathrm{E}_{1(0)}\right)$ can be reduced by increasing milk yield and energetic efficiency of milk production or by reducing energy expenditure for maintenance. The selection of dairy cows with high energy utilization efficiencies and milk productivity offers an effective approach to reducing enteric $\mathrm{CH}_{4}$ emission rates.

Key words: dairy cow, energy utilization efficiency, methane energy output, mitigation strategy

\section{INTRODUCTION}

Methane $\left(\mathrm{CH}_{4}\right)$ is a greenhouse gas that remains in the atmosphere for approximately 9 to $15 \mathrm{yr}$. Methane is over 20 times more effective in trapping heat in the atmosphere than carbon dioxide $\left(\mathrm{CO}_{2}\right)$ over a 100-yr period and is emitted from a variety of natural and human-influenced sources (United States Environmental Protection Agency, 2007). Livestock farming is a major contributor to atmospheric $\mathrm{CH}_{4}$ accumulation. The enteric fermentation of ruminants accounts for a major part of total $\mathrm{CH}_{4}$ emissions from livestock farming, especially in Europe, North America, Australia, and New Zealand, where beef, lamb, and milk are major food sources for humans. Globally, the livestock sector produces $37 \%$ of all human-induced $\mathrm{CH}_{4}$ (Steinfeld et al., 2006). At present, there is increasing pressure to reduce greenhouse gases (GHG) from all sectors of the economy. Recent European Union legislation requests that member nations reduce total GHG from 1990 levels by $20 \%$ by 2020 (European Union, 2008), and the UK Climate Change Act (UK Office of Public Sector Information, 2008) sets a target of $80 \%$ reduction from 1990 levels by 2050. The implementation of these targets will have major implications for ruminant livestock systems.

Consequently, there is increasing interest in research to reduce enteric $\mathrm{CH}_{4}$ emissions from ruminant animals. 
Table 1. Summary statistics for animal and dietary variables used in model development

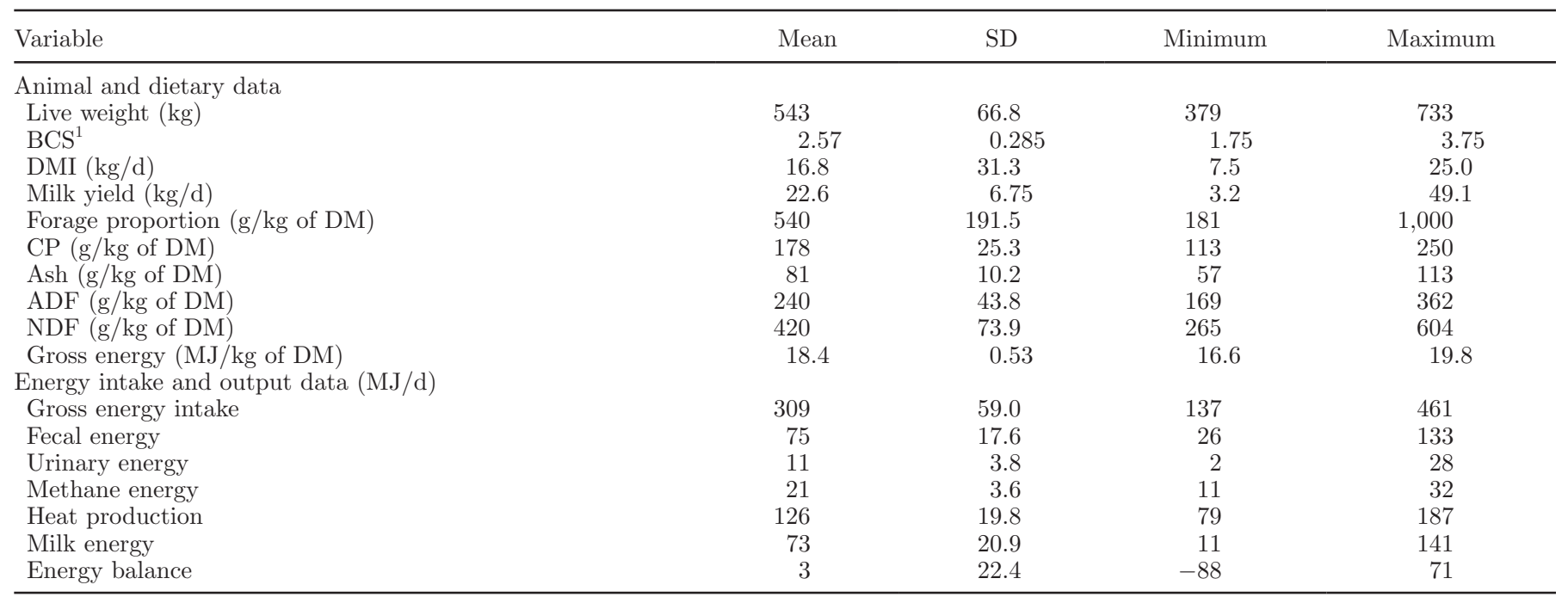

${ }^{1}$ The BCS of each cow was determined using the method described by Mulvanny (1977), with 5 categories from 1 (very thin) to 5 (very fat).

Many approaches have been shown to reduce enteric $\mathrm{CH}_{4}$ emissions from ruminant animals, such as use of dietary additives (e.g., oil, ionospheres), defaunation (elimination of protozoa), and immunization (Moss et al., 2000; Boadi et al., 2004). Although some of these strategies have potential, they have not yet been demonstrated to work in practice. Under normal feeding regimens, $\mathrm{CH}_{4}$ emissions from cattle vary greatly. For example, $\mathrm{CH}_{4}$ energy $\left(\mathbf{C H}_{4}-\mathbf{E}\right)$ output as a percentage of gross energy (GE) intake ranged from 1.6 to $9.9 \%$ in 404 trials with Holstein cows in the United States (Moe and Tyrrell (1979), and from 3.7 to $10.1 \%$ in 247 Holstein-Friesian cows in United Kingdom (Yan et al., 2000). The large range in proportional $\mathrm{CH}_{4}$ emissions can be attributed to both animal and dietary factors (Ellis et al., 2007; Yan, 2009). However, there is little information in the literature on $\mathrm{CH}_{4}$ emission rates among lactating dairy cows with different capacities in energy partitioning and energy utilization efficiencies.

At the Agri-Food and Biosciences Institute, several studies with dairy cattle have been undertaken to evaluate effects of changes in dietary and animal factors on energy metabolism including $\mathrm{CH}_{4}$ output using indirect open-circuit respiration calorimeter chambers. The objectives of the present study were to use these data to evaluate relationships between $\mathrm{CH}_{4}$-E output and a range of variables in animal production, energy partitioning, and energy utilization efficiency in lactating dairy cows under normal feeding regimens. The data presented in the present study were derived from indoor-feeding cows offered diets based on grass silage and fresh grass. The possible effects of management and dietary factors should be considered if results obtained in the present study are applied to dairy cows on grazing or offered diets based on nongrass silage and nonfresh grass.

\section{MATERIALS AND METHODS}

\section{Animals, Diets, and Methane Measurements}

The data set used in the present study was obtained from 579 lactating dairy cows (511 Holstein-Friesian, 36 Norwegian, and 32 Jersey-Holstein) in 20 energy metabolism studies undertaken at the Agri-Food and Biosciences Institute of Northern Ireland (Large Park, Hillsborough, UK) from 1993 to 2007. The animals used were of various milk yield potential, lactation number (1-9), stage of lactation (early to late), BCS (1.75-3.75), and live weight $(379-747 \mathrm{~kg})$. The BCS of each cow was determined using the method described by Mulvanny (1977), with 5 categories from 1 (very thin) to 5 (very fat). Milk yields during energy metabolism measurements ranged from 3.2 to $49.1 \mathrm{~kg} / \mathrm{d}$. Table 1 presents mean, standard deviation, and range of data for live weight and milk yield.

The majority of cows were offered grass silage-based diets $(\mathrm{n}=550)$ and the remaining animals were given fresh grass-based diets $(\mathrm{n}=29)$. All silage and fresh grass was harvested from perennial ryegrass swards. The grass silages encompassed primary growth and first and second regrowth material. Grass was either unwilted or wilted before ensiling and ensiled with or without application of silage additives. A total of 48 cows were offered forage as the sole diet, but otherwise all other cattle $(\mathrm{n}=531)$ were offered forages with a proportions of concentrates ranging from 181 to $869 \mathrm{~g} / \mathrm{kg}$ of DM, with a mean of 498 (SD 137.7). The concentrates 
Table 2. The linear relationships between methane energy output as a proportion of energy intake or milk energy output and milk energy, energy intake, and energy metabolizability ${ }^{1}$

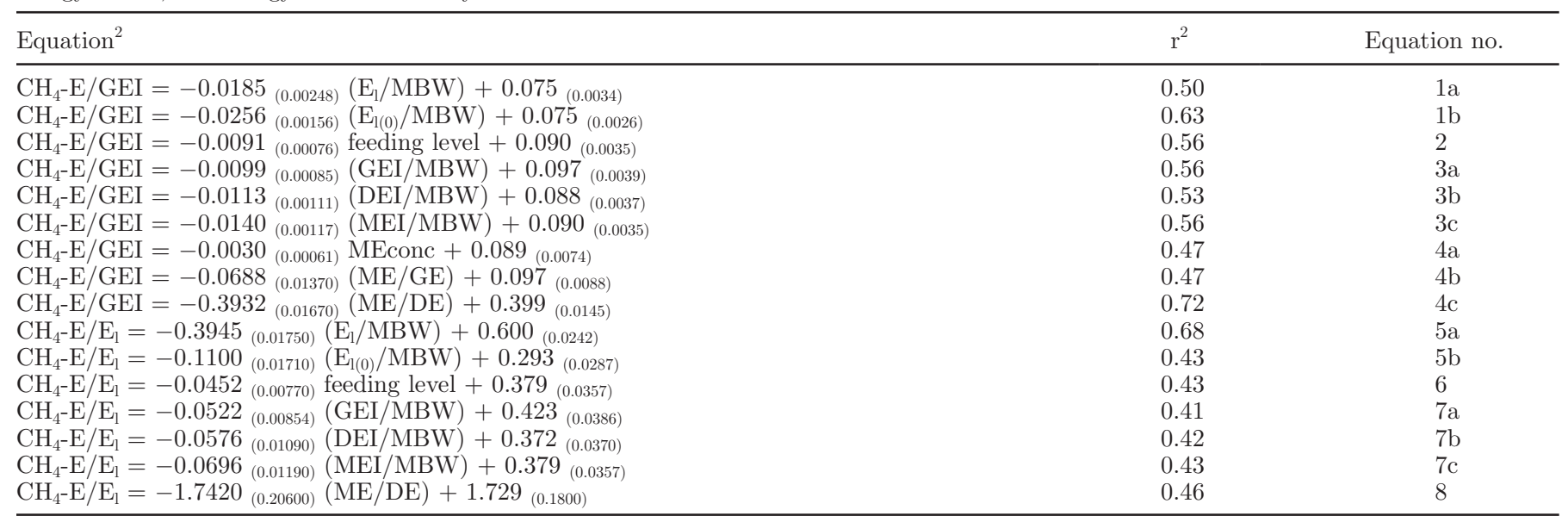

${ }^{1}$ The experimental effect on each relationship was removed. Values in subscript parentheses are SE. All relationships are significant $(P<$ $0.001)$.

${ }^{2} \mathrm{CH}_{4}-\mathrm{E}=$ methane energy output (MJ/d); GEI, DEI, and MEI = gross energy (GE), digestible energy (DE), and ME intake, respectively $(\mathrm{MJ} / \mathrm{d}) ; \mathrm{E}_{\mathrm{l}}=$ milk energy output $(\mathrm{MJ} / \mathrm{d}) ; \mathrm{MBW}=$ metabolic $\mathrm{BW}\left(\mathrm{kg}^{0.75}\right) ; \mathrm{E}_{1(0)}=$ milk energy output adjusted to zero energy balance $(\mathrm{MJ} / \mathrm{d}) ;$ $\mathrm{MEconc}=\mathrm{ME}$ concentration $(\mathrm{MJ} / \mathrm{kg}$ of $\mathrm{DM}) ;$ unit for $\mathrm{GE}, \mathrm{DE}$, and $\mathrm{ME}=\mathrm{MJ} / \mathrm{kg}$ of DM.

used in each of the studies included a mineral-vitamin supplement and some of the following ingredients: cereal grains (barley, wheat, or maize), byproducts (maize gluten meal, molassed or unmolassed sugar-beet pulp, citrus pulp, or molasses), and protein supplements (fish meal, soybean meal, or rapeseed meal). The concentrate portion of the diet was offered either in a complete diet mixed with forage or as a separate feed from forage. All animals were offered either forage or the complete diet ad libitum. The data on mean, standard deviation, and range for DM intake, dietary chemical composition, and energy intake and outputs are presented in Table 1.

Gaseous exchange (oxygen inhaled, $\mathrm{CH}_{4}$ and carbon dioxide exhaled; L/d) was measured using indirect open-circuit respiration calorimeter chambers. The gaseous exchange data were used for calculation of $\mathrm{CH}_{4}-\mathrm{E}$ output and heat production (HP), with urinary energy output adjusted using equations of Brouwer (1965). Prior to commencing energy metabolism measurements, all cows were offered experimental diets for at least 3 wk in group-housed pens in cubicle accommodation, with free access to drinking water. All equipment, procedures, analytical methods, and calculations used in the calorimetric experiments were as reported by Gordon et al. (1995), and calibration of the chambers by Yan et al. (2000).

\section{Statistical Analyses}

Feeding level was calculated from ME intake (MEI) divided by $\mathrm{ME}$ requirement for maintenance $\left(\mathbf{M E _ { M }}\right)$, which was estimated from the model of Agnew et al.
(2004). This model has been widely accepted in the United Kingdom as a basis for rationing dairy cows. Milk energy output $\left(\mathbf{E}_{1}\right)$ adjusted to zero energy balance $\left[\mathbf{E}_{1(0)}\right]$ was estimated from equation [a] and the efficiency of utilization of ME for lactation $\left(\mathbf{k}_{\mathbf{l}}\right)$ was calculated from equation $[\mathrm{b}]$ :

$$
\begin{gathered}
\mathrm{E}_{1(0)}=\mathrm{E}_{1}+\mathrm{a} \times \text { energy balance, } \\
\mathrm{k}_{\mathrm{l}}=\mathrm{E}_{\mathrm{l}(0)} /\left(\mathrm{MEI}-\mathrm{ME}_{\mathrm{M}}\right),
\end{gathered}
$$

where $\mathrm{a}=0.95$ for positive energy balance and $\mathrm{a}=$ -0.84 for negative energy balance (AFRC, 1990). The unit for $\mathrm{ME}$ intake, energy balance, $\mathrm{E}_{1}, \mathrm{E}_{1(0)}$, and $\mathrm{ME}_{\mathrm{M}}$ was $\mathrm{MJ} / \mathrm{kg}^{0.75} ; \mathrm{ME}_{\mathrm{M}}$ was calculated from the model of Agnew et al. (2004).

Linear and quadratic regression techniques were used to evaluate relationships between proportional $\mathrm{CH}_{4}-\mathrm{E}$ data and a range of variables associated with energy intake, milk energy output, energy metabolizability, energy partitioning, and energy utilization efficiency. The effect of experiment on these linear and quadratic regression equations, presented in Tables 2 and 3, was removed using the following models ([c] and $[\mathrm{d}]$ ).

$$
\begin{gathered}
y=a i+b \times x, \\
y=a i+b \times x+c \times x^{2},
\end{gathered}
$$

where $\mathrm{y}=$ response variable; $\mathrm{ai}=$ effect of experiment i for $i=1$ to $20 ; b=$ coefficient for linear relationship; 
Table 3. The relationships between methane energy output expressed as a proportion and energetic efficiency variables ${ }^{1}$

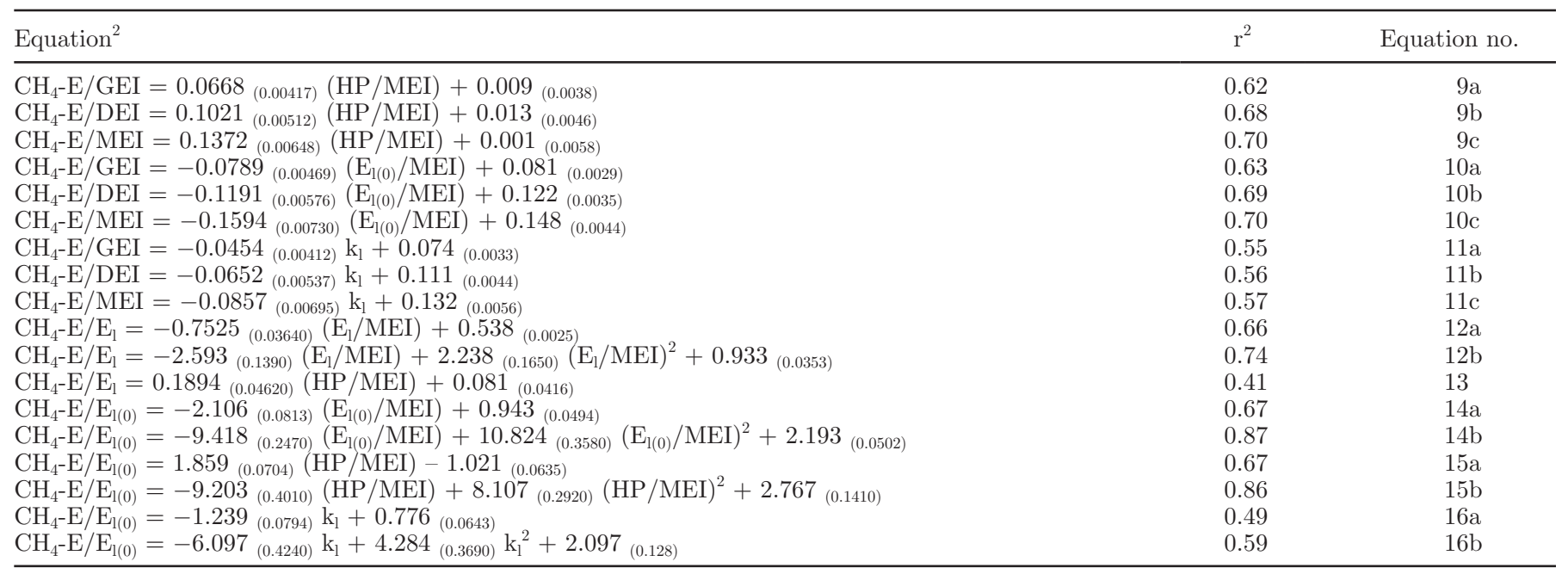

${ }^{1}$ The experimental effect on each relationship was removed. Values in subscript parentheses are SE. All relationships are significant $(P<$ $0.001)$.

${ }^{2} \mathrm{CH}_{4}$-E = methane energy output (MJ/d); GEI, DEI, and MEI = gross energy (GE), digestible energy (DE), and ME intake, respectively $(\mathrm{MJ} / \mathrm{d}) ; \mathrm{HP}=$ heat production $(\mathrm{MJ} / \mathrm{d}) ; \mathrm{E}_{1(0)}=$ milk energy output adjusted to zero energy balance (MJ/d); $\mathrm{k}_{1}=$ efficiency of utilization of ME for lactation; $\mathrm{E}_{\mathrm{l}}=$ milk energy output $(\mathrm{MJ} / \mathrm{d})$.

$\mathrm{x}=$ explanatory variable; and $\mathrm{c}=$ coefficient for quadratic relationship.

The statistical program used in the present study was Genstat 10.1 (tenth edition, Lawes Agricultural Trust, Rothamsted, UK). Including experiment factor in the model, the statistical program produced a range of submodels for each response variable (energy intake, milk energy output, energy metabolizability, energy partitioning, and energy utilization efficiency). These submodels had parallel lines (coefficients) and different constants. The latter was determined using experiment 1 as reference level. The differences in constants were then adjusted using their associated standard error values to produce a common equation.

\section{RESULTS}

\section{Relationships Between Methane Energy Output and Energy Metabolism Variables}

The $\mathrm{CH}_{4}$-E as a proportion of metabolic BW (MBW; $\left.\mathrm{kg}^{0.75}\right)$ was negatively related to $\mathrm{MBW}(P<0.001)$, whereas it was positively related to feeding level, energy intake [GE, digestible energy (DE), and ME], and energy outputs in feces, urine, $\mathrm{HP}$, and milk and $\mathrm{E}_{1(0)}$ when these energy variables were expressed as a proportion of MBW $(P<0.001)$. The MBW had a positive relationship with $\mathrm{CH}_{4}-\mathrm{E} / \mathrm{E}_{1}(P<0.01)$. Feeding level and all energy intake and output variables as a proportion of $\mathrm{MBW}$ were negatively related to $\mathrm{CH}_{4}-\mathrm{E}$ as a proportion of GE, DE, and ME intake, $\mathrm{E}_{1}$, and $\mathrm{E}_{1(0)}(P$ $<0.001$ ), except for the positive relationship between energy balance as a proportion of $\mathrm{MBW}$ and $\mathrm{CH}_{4}-\mathrm{E} /$ $\mathrm{E}_{1}(P<0.001)$.

The $\mathrm{CH}_{4}-\mathrm{E}$ as a proportion of $\mathrm{MBW}$ was negatively related to $\mathrm{HP} / \mathrm{ME}$ intake and $\mathrm{k}_{1}(P<0.001)$, whereas it was positively related to dietary $\mathrm{ME}$ concentration $(P$ $<0.05), \mathrm{ME} / \mathrm{GE}$, and $\mathrm{ME} / \mathrm{DE}(P<0.001)$. The $\mathrm{CH}_{4}-\mathrm{E}$ as a proportion of GE, DE, and ME intake, $\mathrm{E}_{1}$, and $\mathrm{E}_{1(0)}$ were all negatively related to $\mathrm{ME}$ concentration, $\mathrm{ME}$ / GE, ME/DE, $\mathrm{E}_{1(0)} / \mathrm{ME}$ intake, and $\mathrm{k}_{1}(P<0.001)$, but positively related to $\mathrm{HP} / \mathrm{ME}$ intake $(P<0.001)$. There was a positive relationship between $\mathrm{DE} / \mathrm{GE}$ and $\mathrm{CH}_{4}{ }^{-}$ $\mathrm{E} / \mathrm{E}_{1}(P<0.05)$. Dietary DE concentration and DE/ GE were negatively related to $\mathrm{CH}_{4}-\mathrm{E}$ as a proportion of $\mathrm{DE}$ and $\mathrm{ME}$ intake and $\mathrm{E}_{1(0)}(P<0.001)$. The $\mathrm{E}_{1} / \mathrm{ME}$ intake was negatively related to $\mathrm{CH}_{4}-\mathrm{E} / \mathrm{GE}$ intake $(P<$ $0.05)$ and $\mathrm{CH}_{4}-\mathrm{E} / \mathrm{E}_{1}(P<0.001)$.

The above relationships indicate that level of animal production, energy metabolizability, partitioning, and utilization efficiency can influence proportional $\mathrm{CH}_{4}-\mathrm{E}$ outputs of dairy cows. Some relationships were therefore selected for further development as potential mitigation strategies for $\mathrm{CH}_{4}-\mathrm{E} / \mathrm{GE}$ intake and $\mathrm{CH}_{4}-\mathrm{E} /$ $\mathrm{E}_{1}$. Relationships with $\mathrm{CH}_{4}-\mathrm{E} / \mathrm{DE}$ intake and $\mathrm{CH}_{4}-\mathrm{E} /$ ME intake were also developed. Their relationships were similar to those with $\mathrm{CH}_{4}-\mathrm{E} / \mathrm{GE}$ intake and thus are not presented.

\section{Effects of Level of Animal Production on Methane Emissions}

The relationships between $\mathrm{CH}_{4}-\mathrm{E} / \mathrm{GE}$ intake (equations [1a] to [3c]) or $\mathrm{CH}_{4}-\mathrm{E} / \mathrm{E}_{1}$ (equations [5a] to [7c]) 

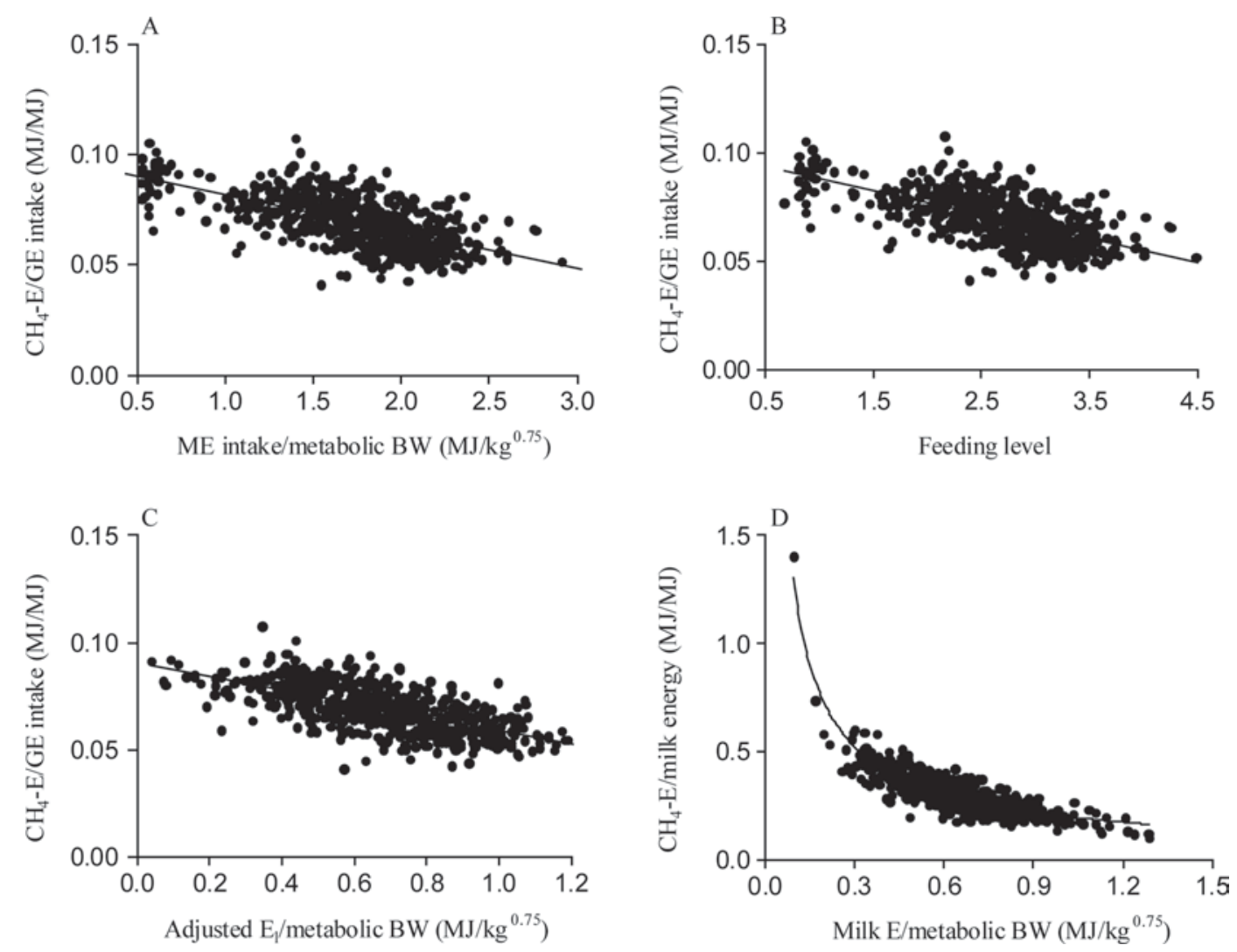

Figure 1. Relationships between $\mathrm{CH}_{4}$ energy output $\left(\mathrm{CH}_{4}-\mathrm{E}\right)$ as a proportion of gross energy (GE) intake or milk energy output and energy intake and milk energy output $\left(\mathrm{E}_{1}\right)$ of dairy cows.

and energy intake/MBW or $\mathrm{E}_{1} / \mathrm{MBW}$ are presented in Table 2; selected relationships are also presented in Figure 1. Increasing $\mathrm{E}_{1} / \mathrm{MBW}$ reduced $\mathrm{CH}_{4}-\mathrm{E} / \mathrm{GE}$ intake and $\mathrm{CH}_{4}-\mathrm{E} / \mathrm{E}_{1}$ and improved the strength of the relationship with $\mathrm{CH}_{4}-\mathrm{E} / \mathrm{GE}$ intake ([1a] vs. $\left.[1 \mathrm{~b}]\right) ; \mathrm{r}^{2}=0.50$ vs. 0.63 ), whereas $\mathrm{CH}_{4}-\mathrm{E} / \mathrm{E}_{1}$ decreased ([5a] vs. [5b]); $\mathrm{r}^{2}$ $=0.68$ vs. 0.43$)$ when using $\mathrm{E}_{1(0)} / \mathrm{MBW}$ to replace $\mathrm{E}_{1} /$ MBW. The $\mathrm{CH}_{4}-\mathrm{E} / \mathrm{GE}$ intake was also reduced with increasing feed intake (feeding level and GE, DE, and ME intake as a proportion of MBW; ([2] to [3c]). The strength of these 4 relationships was similar, with correlation coefficient values ranging from 0.53 to 0.56 . The relationships between $\mathrm{CH}_{4}-\mathrm{E} / \mathrm{E}_{1}$ and these energy intake variables were also negative $\left(\mathrm{r}^{2}=0.41\right.$ to 0.43 ; [6] to [7c]), but correlation coefficient values in these relationships were lower than those in the relationships with $\mathrm{CH}_{4}$-E/GE intake.

\section{Effects of Energy Metabolizability on Methane Emissions}

The relationships between $\mathrm{CH}_{4}$ - $\mathrm{E}$ as a proportion of GE intake ([4a] to [4c]) and $\mathrm{E}_{1}([8])$ and energy metabolizability are presented in Table 2; selected relation- ships are also presented in Figure 2A and B. Increasing dietary $\mathrm{ME}$ concentration and $\mathrm{ME} / \mathrm{GE}$ reduced $\mathrm{CH}_{4}{ }^{-}$ $\mathrm{E} / \mathrm{GE}$ intake, and the strength of these relationships became stronger when using ME/DE to replace dietary ME concentration and ME/GE ([4a] and [4b] vs. [4c]); $\mathrm{r}^{2}=0.47$ and 0.47 vs. 0.72 ). There was a negative relationship between $\mathrm{CH}_{4}-\mathrm{E} / \mathrm{E}_{1}$ and $\mathrm{ME} / \mathrm{DE}\left([8] ; \mathrm{r}^{2}=\right.$ $0.46)$.

\section{Effects of Energy Partitioning and Utilization Efficiency on Methane Emissions}

The relationships between $\mathrm{CH}_{4}-\mathrm{E}$ as a proportion of energy intake ([9a] to [11c]), $\mathrm{E}_{1}$ ([12a] to [14]), and $\mathrm{E}_{1(0)}$ ([15a] to $[17 \mathrm{~b}])$ and energy partitioning and utilization efficiency are presented in Table 3; selected relationships are also presented in Figure $2 \mathrm{C}$ to F. The $\mathrm{CH}_{4}-\mathrm{E} /$ GE intake increased linearly with increasing energy expenditure for maintenance and inefficiency of $\mathrm{ME}$ use for production (HP/ME intake; [9a]), whereas it decreased with increasing energy partitioning toward production (milk and body tissue; [10a]) or increasing energy utilization efficiency $\left(\mathrm{k}_{\mathrm{l}}\right.$; [11a]). These relationships were marginally improved when using $\mathrm{CH}_{4}$-E/ 

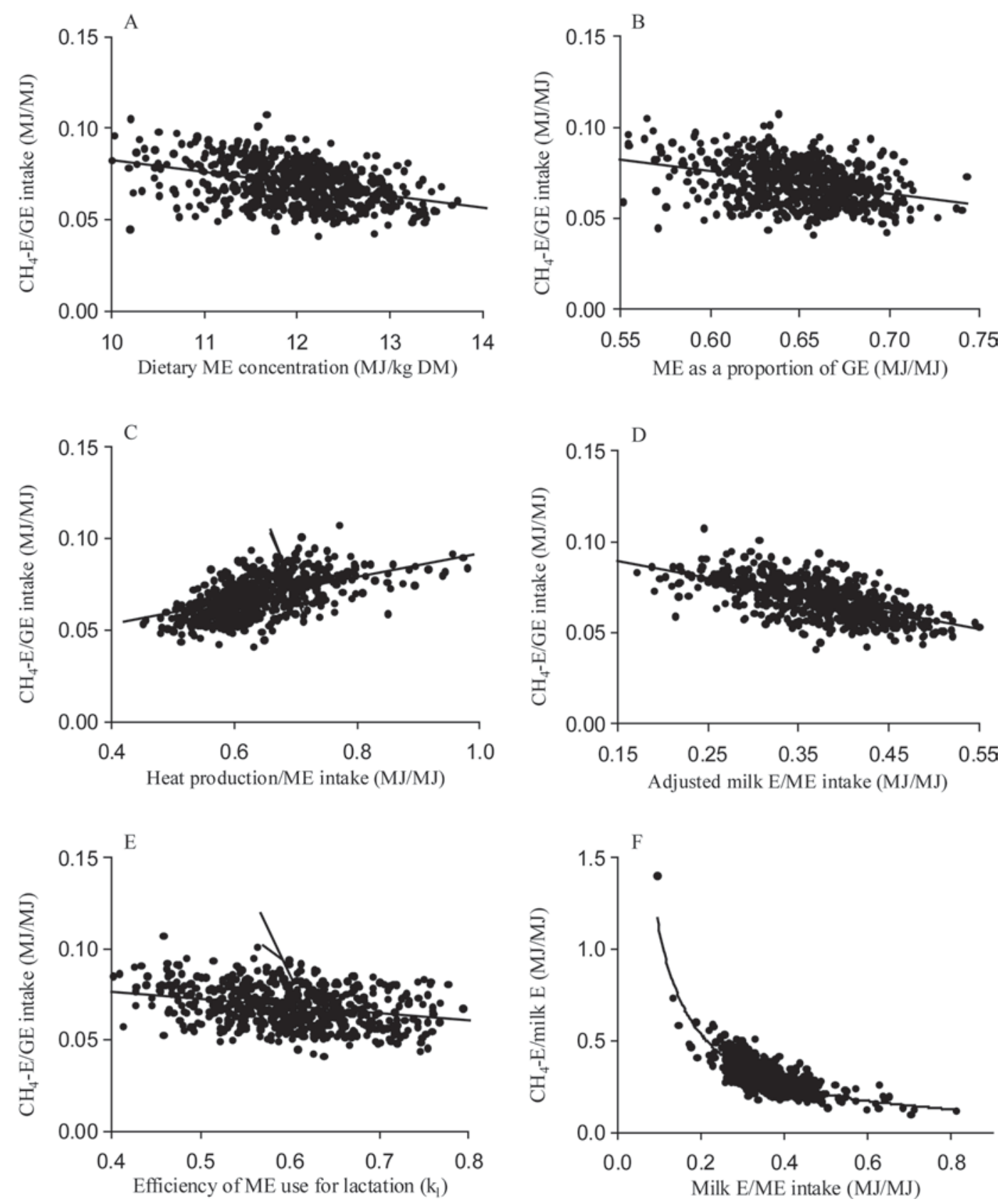

Figure 2. Relationships between $\mathrm{CH}_{4}$ energy output $\left(\mathrm{CH}_{4}-\mathrm{E}\right)$ as a proportion of gross energy (GE) intake or milk energy (milk E) output and energy metabolizability, energy partitioning, and energy utilization efficiency in dairy cows.

DE intake or $\mathrm{CH}_{4}-\mathrm{E} / \mathrm{ME}$ intake to replace $\mathrm{CH}_{4}-\mathrm{E} / \mathrm{GE}$ intake against $\mathrm{HP} / \mathrm{ME}$ intake $([9 \mathrm{~b}]$ or $[9 \mathrm{c}]$ vs. $[9 \mathrm{a}]) ; \mathrm{r}^{2}$ $=0.68$ or 0.70 vs. 0.62$), \mathrm{E}_{1(0)} / \mathrm{ME}$ intake $([10 \mathrm{~b}]$ or $[10 \mathrm{c}]$ vs. $[10 \mathrm{a}]) ; \mathrm{r}^{2}=0.70$ or 0.69 vs. 0.63$)$, or $\mathrm{k}_{1}([11 \mathrm{~b}]$ or $[11 \mathrm{c}]$ vs. $[11 \mathrm{a}]) ; \mathrm{r}^{2}=0.56$ or 0.57 vs. 0.55$)$.

Similar linear relationships were also observed with $\mathrm{CH}_{4}-\mathrm{E} / \mathrm{E}_{1}$ against the above energy utilization efficiency variables, although correlation coefficient value in the relationship with $\mathrm{HP} / \mathrm{ME}$ intake was relatively low $(0.41 ;[13])$. The correlation coefficient value was relatively high in the relationship between $\mathrm{CH}_{4}-\mathrm{E} / \mathrm{E}_{1}$ and $\mathrm{E}_{1} / \mathrm{ME}$ intake and further increased in the quadratic relationship ( 0.66 vs. $0.74 ;[12 \mathrm{a}]$ vs. $[12 \mathrm{~b}])$. Replacement of $\mathrm{CH}_{4}-\mathrm{E} / \mathrm{E}_{1}$ with $\mathrm{CH}_{4}-\mathrm{E} / \mathrm{E}_{1(0)}$ increased the correlation coefficient values in the linear relationships with $\mathrm{HP} / \mathrm{ME}$ intake and $\mathrm{k}_{1}$ to 0.67 and 0.49 ([15a] and [16a]), although the correlation coefficient values in the linear relationship between $\mathrm{CH}_{4}-\mathrm{E} / \mathrm{E}_{1(0)}$ and $\mathrm{E}_{1(0)} / \mathrm{ME}$ 
intake were similar to those between $\mathrm{CH}_{4}-\mathrm{E} / \mathrm{E}_{1}$ and $\mathrm{E}_{1} /$ ME intake (0.67 vs. 0.66 ; [14a] vs. [12a]). Fitting the 3 sets of data in quadratic equations rather than linear relationships considerably improved the relationships, with correlation coefficient values increasing to 0.59 to 0.87 ([14b], [15b], and [16b]).

\section{DISCUSSION}

Under normal feeding regimens used in dairy cow production systems, research on mitigation of enteric $\mathrm{CH}_{4}$ emissions from dairy cows has concentrated on the effects of level of animal production, dietary manipulation of nutrient supply, and dietary supplementation with additives. Several studies, using a meta-analysis approach with large data sets, indicated that proportional $\mathrm{CH}_{4}$ emissions could be reduced with increasing levels of milk production, using high concentrate diets, or decreasing dietary NDF/ADF concentration (Ellis et al., 2007; Capper et al., 2009; Yan, 2009). However, there is little information on the variation in enteric $\mathrm{CH}_{4}$ emissions from dairy cows with different capacities for energy partitioning or energetic efficiency. This may be attributed to the lack of information because the majority of published data sets do not present any energy metabolism data. Therefore, the aim of the present study was to take the research further to evaluate relationships between enteric $\mathrm{CH}_{4}$ emission rates and a range of energy utilization efficiency variables (energy intake, energy partitioning, and energy utilization efficiency) in lactating dairy cows, using energy metabolism data measured in calorimeter chambers. It should be noted that these results were derived from indoor-feeding cows offered diets based on grass silage and fresh grass. Therefore, application of the present results to grazing cows or cows offered diets based on nongrass silage and nonfresh grass should take account of the possible effects of management and dietary factors because rumen fermentation and energy intake and outputs of cows can be altered by dietary manipulation and feeding regimens (Agnew and Yan, 2000).

\section{Effects of Feeding Level and Milk Production on Enteric Methane Emissions}

It is well documented that an increase in feeding level increases the outflow rate of digesta in the rumen with less time available for microbial fermentation of the diet. The consequence is a reduction in ruminal nutrient digestion as well as a decrease in $\mathrm{CH}_{4}$ production in the rumen. Moe and Tyrrell (1979) reported that increasing feeding level changed production rates of $\mathrm{CH}_{4}$-E from digestible soluble residues and digestible cellulose in diets of dairy cows. In a review of studies in the literature with beef cattle, Johnson et al. (1991) reported that, under most circumstances, increasing intake by 1 multiple of maintenance reduced $\mathrm{CH}_{4}$ - $\mathrm{E}$ by proportionately 0.018 of GE intake. Blaxter and Clapperton (1965) reported a reduction in $\mathrm{CH}_{4}-\mathrm{E} / \mathrm{GE}$ intake by $\mathrm{b}$ (where $\mathrm{b}=0.050 \mathrm{DE} / \mathrm{GE}-0.0237$ ) with each increment of 1 feeding level, based on combined data of sheep and beef cattle given mostly nongrass silage diets, where $\mathrm{DE} / \mathrm{GE}$ was measured at maintenance. This equation indicated that the effect of feeding level on $\mathrm{CH}_{4}-\mathrm{E}$ decreased as dietary energy digestibility at maintenance reduced.

In the present study, $\mathrm{CH}_{4}-\mathrm{E}$ as a proportion of $\mathrm{GE}$ intake or $\mathrm{E}_{1}$ significantly reduced with increasing feeding level and $\mathrm{E}_{1}$ as a proportion of MBW. The negative relationships are mainly derived from the fact that $\mathrm{CH}_{4}$ emission associated with maintenance accounts for a lower proportion of total $\mathrm{CH}_{4}$ output, with increasing feeding levels. Furthermore, the $\mathrm{CH}_{4}$ emission rate at maintenance feeding level is higher than that at feeding levels above maintenance because the passage rates of digesta in the rumen are lower at maintenance feeding level. In the present study, $\mathrm{CH}_{4}-\mathrm{E}$ as a proportion of GE intake or $\mathrm{E}_{1}$ significantly reduced with increasing feeding level and energy intake (GE, DE, and $\mathrm{ME}$ ) as a proportion of $\mathrm{MBW}$. The $\mathrm{CH}_{4}-\mathrm{E}$ as a proportion of GE intake reduced proportionately by 0.0091 with each increase in feeding level above maintenance, with $\mathrm{ME}_{\mathrm{M}}$ calculated from Agnew et al. (2004). This equation demonstrates that $\mathrm{CH}_{4}-\mathrm{E}$ is $8.49 \%$ of GE intake at maintenance feeding level, and the corresponding values are $7.18,6.27,5.36$, and $4.45 \%$ with feeding levels of 2 , 3,4 , and 5 , respectively. This dilution of maintenance is a major factor for high producing animals with a low rate of methane emissions (Bauman et al., 1985; Yan et al., 2005; Capper et al., 2009). Consequently, to produce a given level of milk production, use of high yielding cows rather than low yielding cows can be an effective approach to reducing enteric $\mathrm{CH}_{4}$ emissions. In practice, measurements of total carbon footprint from different milk production systems need to take account of emissions of $\mathrm{CH}_{4}$ from not only enteric fermentation but also manure management and, more importantly, emissions of $\mathrm{CO}_{2}, \mathrm{CH}_{4}$, and $\mathrm{N}_{2} \mathrm{O}$ from associated sources (e.g., replacement rate, feed production, fertilizer application, soil, fuel burning, electricity use, and so on). Increasing milk production potential of pasture-fed dairy cows is always related to a reduction in fertility and associated increase in replacement rate. This may offset the reduction in proportional enteric $\mathrm{CH}_{4}$ emissions of 
high yielding cows in a life cycle analysis of total GHG emissions from dairy cow production systems (Lovett, et al., 2006).

\section{Effects of Dietary Energy Metabolizability on Enteric Methane Emissions}

A previous study undertaken at Agri-Food and Biosciences Institute reported a negative relationship between dietary $\mathrm{ME}$ concentration and $\mathrm{CH}_{4}$ emission as a proportion of GE intake in dairy cows offered diets containing grass silages (Yan, 2009). A similar result was also reported in the present study. The $\mathrm{CH}_{4}-\mathrm{E}$ output as a proportion of GE intake significantly decreased with increasing dietary ME concentration, ME/GE, and $\mathrm{ME} / \mathrm{DE}$. A similar relationship was also observed between $\mathrm{CH}_{4}-\mathrm{E}$ output as a proportion of $\mathrm{E}_{1}$ and dietary $\mathrm{ME} / \mathrm{DE}$. The ME concentration in mixed diets normally depends on the quality of forage and concentrates and proportion of forage in total diets. Under normal feeding regimens, poor quality diets usually contain a higher proportion of poor quality forages. Methane output in the rumen is associated with production of acetic acid, and in general, fermentation of high forage diets results in a higher molar proportion of acetic acid than that obtained with high concentrate diets (Ørskov and Ryle, 1990). Several review papers in the literature indicate a positive relationship between $\mathrm{CH}_{4}-\mathrm{E}$ and forage proportion in diet. For example, Johnson et al. (1991) reported that $\mathrm{CH}_{4}$ - $\mathrm{E}$ in beef cattle offered high concentrate diets always accounted for a low proportion of GE intake (0.044). Johnson et al. (1991) noted a very low rate of $\mathrm{CH}_{4}$-E/GE intake (0.02) in several cases when diets contained 0.90 of concentrates. Moe and Tyrrell (1979) related $\mathrm{CH}_{4}-\mathrm{E}$ to total intakes of digestible nutrients of soluble residue, hemicelluloses, and cellulose. Coefficients for the latter 2 variables were 1.875 and 5.103 times higher, respectively, than for the former variable, indicating a higher rate of $\mathrm{CH}_{4}-\mathrm{E}$ from fiber than from starch. Holter and Young (1992) also observed that $\mathrm{CH}_{4}-\mathrm{E}$ was positively related to forage proportion in diet; hence, in their prediction equation, dietary ADF concentration was used as a predictor. Results from the present study and previous publications indicate that use of high quality feeds (e.g., feeds with high ME concentrations) is an effective approach to reducing enteric methane emissions from dairy cows under normal production systems used in practice.

\section{Effects of Energetic Efficiency on Enteric Methane Emissions}

The genetic merit of dairy cows has improved considerably across the world during the last several decades.
Improvements in milk production are derived from increased feed intake and from altered energy partitioning between milk and body tissue. High yielding cows have the ability to partition more consumed energy into milk and less into body tissue when compared with low to medium yielding cows (Veerkamp and Emmans, 1995; Agnew and Yan, 2000; Yan et al., 2006). These changes can influence energy metabolism of cows (Agnew and Yan, 2000). However, there is little information in the literature on the relationship between $\mathrm{CH}_{4}$ emission rate and energetic efficiency of lactating dairy cows.

A range of approaches was used in the present study to evaluate effects of energy partitioning on proportional $\mathrm{CH}_{4}$ emission of dairy cows. The $\mathrm{CH}_{4}$ - $\mathrm{E}$ as a proportion of energy intake (GE, DE, and ME) increased with increasing energy expenditure on maintenance and inefficiency of ME use for production (HP/ME intake), whereas it reduced with increases in the proportion of ME intake directed to milk production and body tissue $\left(\mathrm{E}_{1(0)} / \mathrm{ME}\right.$ intake). For example, a reduction of $\mathrm{HP}$ as a proportion of ME intake from 100, 70, to $40 \%$ could reduce $\mathrm{CH}_{4}$-E output as a proportion of GE intake from $7.6,5.6$, to $3.6 \%$, respectively. Similar linear relationships were also observed with $\mathrm{CH}_{4}-\mathrm{E}$ as a proportion of $\mathrm{E}_{1}$ and $\mathrm{E}_{1(0)}$ against the ME partitioning variables. Furthermore, negative relationships were observed between $\mathrm{k}_{1}$ and $\mathrm{CH}_{4} \mathrm{E}$ as a proportion of energy intake (GE, $\mathrm{DE}$, and $\mathrm{ME})$ and $\mathrm{E}_{1(0)}$. Again, a quadratic relationship between $\mathrm{CH}_{4}-\mathrm{E} / \mathrm{E}_{1(0)}$ and $\mathrm{k}_{1}$ produced a better correlation coefficient value than a linear relationship $\left(\mathrm{r}^{2}=\right.$ 0.49 vs. 0.59$)$.

Increasing ME intake with high yielding cows increases feeding levels and consequently reduces the proportion of energy used for maintenance. This leads to a reduction in $\mathrm{CH}_{4}$-E output as a proportion of energy intake with high yielding cows. The present study demonstrated a negative relationship between proportional $\mathrm{CH}_{4}-\mathrm{E}$ output and feeding levels and energy intake (GE, DE, and ME). Furthermore, increasing ME intake would normally result in a high proportion of energy being partitioned to milk production and body tissue retention, or a low ratio of HP over ME intake. A combination of these 2 factors therefore increases the possibility of a low proportional $\mathrm{CH}_{4}$-E output for high yielding cows. Indeed, in the present study, proportional $\mathrm{CH}_{4}-\mathrm{E}$ output was strongly and negatively related to $\mathrm{E}_{1(0)} / \mathrm{ME}$ intake and positively related to $\mathrm{HP} / \mathrm{ME}$ intake.

However, the effect of feeding level on proportional $\mathrm{CH}_{4}$-E output could be removed when relating the latter to $\mathrm{k}_{1}$ values because $\mathrm{k}_{1}$ value is calculated from energy retained in milk and body tissue $\left(\mathrm{E}_{1(0)}\right)$ and $\mathrm{ME}$ available for production $\left(\mathrm{ME}_{\mathrm{P}}=\mathrm{ME}\right.$ intake $-\mathrm{ME}_{\mathrm{M}} ; \mathrm{k}_{1}=\mathrm{E}_{1(0)} /$ $\left.\mathrm{ME}_{\mathrm{P}}\right)$. The $\mathrm{k}_{1}$ values are relatively independent of level of animal production (milk yield and ME intake; Agnew 
and Yan, 2000; Yan et al., 2006). In the present study, a negative relationship was observed between $k_{1}$ value and $\mathrm{CH}_{4}-\mathrm{E}$ output as a proportion of $\mathrm{E}_{1(0)}$ and energy intake (GE, DE, and ME). This clearly demonstrates that the cows with a high energy utilization efficiency produce a low rate of $\mathrm{CH}_{4}$ - $\mathrm{E}$ output. Breeding for cows with a high energetic efficiency is thus an effective approach to reducing $\mathrm{CH}_{4}$ emissions. The evaluation of energetic efficiency requires information on ME intake and energy partitioning between milk and body tissue, which may not be available in practice.

\section{CONCLUSIONS}

The present study evaluated relationships between methane emissions and a range of factors for level of animal production and energy utilization efficiency in lactating dairy cows offered diets containing grass silage or fresh grass, using calorimetric data from 20 studies. The results indicate that methane energy output as a proportion of GE intake or milk energy output was negatively related to levels of milk production, energy metabolizability, and the efficiency of utilization of ME for lactation. Therefore, selection of dairy cows capable of high levels of milk production and energy utilization efficiency offers an effective approach to reducing $\mathrm{CH}_{4}$ emissions from lactating dairy cows.

\section{ACKNOWLEDGMENTS}

This study was funded by the Department of Agriculture and Food of the Republic of Ireland (Dublin) through a Research Stimulus Fund Program (RSFP 07 - 517), with co-funding from the Department of Agriculture and Rural Development of Northern Ireland (Belfast). The authors thank their colleagues at the Agri-Food and Bioscience Institute (Hillsborough, UK) for experimental data used in the present study.

\section{REFERENCES}

Agnew, R. E., and T. Yan. 2000. The impact of recent research on energy feeding systems for dairy cattle. Livest. Prod. Sci. 66:197215.

Agnew, R. E., T. Yan, J. France, E. Kebreab, and C. Thomas. 2004. Energy requirement and supply. Pages $11-20$ in Feed into Milk: A New Applied Feeding System for Dairy Cows. C. Thomas, ed. Nottingham Univ. Press, Nottingham, UK.

Agricultural and Food Research Council. 1990. Nutritive requirements of ruminant animals: Energy. Technical Committee on Responses to Nutrients, Report No. 5. Nutr. Abs. Rev. (Series B) 60:729804 .

Bauman, D. E., S. N. McCutcheon, W. D. Steinhour, P. J. Eppard, and S. J. Sechen. 1985. Sources of variation and prospects for improvement of productive efficiency in the dairy cow: A review. J. Anim. Sci. 60:583-592.
Blaxter, K. L., and J. L. Clapperton. 1965. Prediction of the amount of methane produced by ruminants. Br. J. Nutr. 19:511-522.

Boadi, D., C. Benchaar, J. Chiquette, and D. Massé. 2004. Mitigation strategies to reduce enteric methane emissions from dairy cows: Update review. Can. J. Anim. Sci. 84:319-335.

Brouwer, E. 1965. Report of sub-committee on constants and factors Page 441 in Energy Metabolism. EAAP Publ. No. 11. EAAP, Troon, UK.

Capper, J. L., R. A. Cady, and D. E. Bauman. 2009. The environmental impact of dairy production: 1944 compared with 2007. J. Anim. Sci. 87:2160-2167.

Ellis, J. L., E. Kebreab, N. E. Odongo, B. W. McBride, E. K. Okine, and J. France. 2007. Prediction of methane production from dairy and beef cattle. J. Dairy Sci. 90:3456-3466.

European Union. 2008. The EU climate and energy package. http:// ec.europa.eu/environment/climat/climate_action.htm Accessed Aug. 1, 2009.

Gordon, F. J., M. G. Porter, C. S. Mayne, E. F. Unsworth, and D. J. Kilpatrick. 1995. The effect of forage digestibility and type of concentrate on nutrient utilisation for lactating dairy cattle. J. Dairy Res. 62:15-27.

Holter, J. B., and A. J. Young. 1992. Methane production in dry and lactating Holstein cows. J. Dairy Sci. 75:2165-2175.

Johnson, D. E., T. M. Hill, B. R. Carmen, M. E. Branine, D. W. Lodman, and G. M. Ward. 1991. New perspectives on ruminant methane emissions. Pages 376-379 in Energy Metabolism of Farm Animals. EAAP Publ. No 58. C. Wenk and M. Boessinger, ed. EAAP, Kartause Ittingen, Switzerland.

Lovett, D. K., L. Shalloo, P. Dillon, and F. P. O'Mara. 2006. A systems approach to quantify greenhouse gas fluxes from pastoral dairy production as affected by management regimen. Agric. Syst. $88: 156-179$

Moe, P. W., and H. F. Tyrrell. 1979. Methane production in dairy cows. J. Dairy Sci. 62:1583-1586.

Moss, A. R., J. Jouany, and J. Newbold. 2000. Methane production by ruminants: Its contribution to global warming. Ann. Zootech. 49:231-253.

Mulvanny, P. M. 1977. Dairy cow condition scoring. Paper 4468. Natl. Inst. Res. Dairying, Reading, UK.

Ørskov, E. R., and M. Ryle. 1990. Energy Nutrition in Ruminants. Elsevier Science Publishers Ltd., London, UK.

Steinfeld, H., P. Gerber, T. Wassenaar, V. Castel, M. Rosales, and C. de Haan. 2006. Livestock's Long Shadow-Environmental Issues and Options. Food and Agriculture Organisation of the United Nations, Rome, Italy.

UK Office of Public Sector Information. 2008. Climate Change Act (2008). http://www.opsi.gov.uk/about/index.htm Accessed Aug. $1,2009$.

United States Environmental Protection Agency. 2007. Methane. http://www.epa.gov/methane Accessed Feb. 1, 2010.

Veerkamp, R. F., and G. C. Emmans. 1995. Sources of genetic variation in energetic efficiency of dairy cows. Livest. Prod. Sci. 44:87-97.

Yan, T. 2009. Development of dietary and animal approaches to reduce methane emission from dairy cattle. Pages 29-30 in Proc. XV Intern. Silage Conf., Univ. Wisconsin-Madison. College of Agricultural Life Sciences, Univ. Wisconsin-Madison.

Yan, T., R. E. Agnew, F. J. Gordon, and M. G. Porter. 2000. The prediction of methane energy output in dairy and beef cattle offered grass silage-based diets. Livest. Prod. Sci. 64:253-263.

Yan, T., C. S. Mayne, T. W. J. Keady, and R. E. Agnew. 2006. Effects of dairy cow genotype (Holstein-Friesian versus Norwegian) with two planes of nutrition on energy partitioning between milk and body tissue. J. Dairy Sci. 89:1031-1042.

Yan, T., C. S. Mayne, and M. G. Porter. 2005. Effects of dietary and animal factors on methane production in dairy cows offered grass silage-based diets. Pages 131-134 in Proc. 2nd Greenhouse Gases and Animal Agriculture Conf., Zurich, Switzerland. ETH Zurich, Zurich, Switzerland. 